\title{
COVID-19 ve Sınırlar: Küresel Salgın Döneminde Sınırların Değişen Anlamı
}

\author{
DOI: $10.26466 /$ opus. 843330
}

*

\section{Kerem Özbey *}

* Doç. Dr., Artvin Çoruh Üniversitesi, Fen-Edebiyat Fakültesi, Sosyoloji Bölümü, Artvin/Türkiye E-Posta: ozbey-kerem@hotmail.com

ORCID: $\quad$ 0000-0001-8824-359X

\section{$\ddot{O} z$}

COVID-19 salgını, milyonlarca insanın yaşamını yitirdiği, hastalı̆̆a yakalandığı ve hayatta kalmak için mücadele verdiği küresel ölçekteki bir sorundur. Insan ve toplum hayatını derinden sarsan bu sorun karşısında farklı çözüm arayışları devam etmektedir. Stnırlar, söz konuısu arayışların bir yansıması olarak belirmiştir. Salgın küresel olsa da, salgınla mücadelenin ulusal düzeyde yapılması sınırların önemini, etkisini ve değerini artırmıştır. Sonuçlar ve çözümler bağlamında küresel salgının sinırları nasıl etkilediği, salgın öncesi ve salginla birlikte sinırlara ne tür anlamlar yüklendiği, salgınla mücadelenin ulus-devletler üzerinden yapılması küreselleşmenin sorgulanmasını nasıl etkilediği, küresel hastalık karşısında tedavinin ulusal olması sınırları ne yönde etkilediği, ulus-devletlerin sınırları içerisinde yaşayanlarla sınırların dışarısında kalanların salgın sürecinde hangi kategorik kimlikler üzerinden tanımlandı̆̆l, sinırların ulusal izolasyonun să̆lanmasinda nasıl bir etkiye sahip olduğu, salgın sürecinde stnırların küresel insan hareketliliğini nasıl şekillendirdiği, küresel salgın koşullarında sinırların değişen milliyetçilik üzerinden ne tür etkilerinin bulunduğu ve Türkiye'nin küresel salgınla mücadelesinde sınırların nasıl bir işleve sahip olduğ $u$ bu çalışmanın sorunsalını oluşturmaktadır. Bu sorunsal çerçevesinde, çalışmada, küresel salgın döneminde sınırların değişen anlamı anlaşılmaya çalışılmıştır.

Anahtar Kelimeler: COVID-19, Küresel Salgın, Sinırlar, Milliyetçilik, Türkiye. 


\title{
COVID-19 and Borders: The Changing Meaning of Borders in a Global Pandemic
}

\begin{abstract}
The COVID-19 pandemic is a global challenge where millions of people die, get sick and struggle to survive. In the face of this problem that deeply shakes human and social life, different solutions are being searched. Borders appeared as a reflection of these searches. Although the epidemic is global, tackling the epidemic at the national level has increased the importance, impact and value of the borders. In the context of results and solutions, how the global epidemic affects borders, what kind of meanings it attributes to borders before and with the epidemic, how the fight against the epidemic through nation-states affects the questioning of globalization, how national treatment in the face of global disease affects borders, with those who live within the borders of nation-states. boundaries in the process of outbreaks of remaining outside, which is defined through categorical identities, how to have an impact in achieving the boundaries of national isolation, epidemic processes within the limits of global human mobility on how to shape what kind where the effect on changing the boundaries of the global epidemic conditions nationalism and Turkey's how the boundaries in the fight against global secretion It is the problematic of this study that it has a function. In this problematic framework, the study attempted to understand the changing meaning of borders during the global epidemic.
\end{abstract}

Keywords: COVID-19, Global Epidemic, Borders, Nationalism, Turkey. 


\section{Giriş}

2019 yılının sonlarında, Çin'in Vuhan kentinden ortaya çıkan COVID-19 salgını, kısa sürede bütün dünyayı etkisi altına almıştır. Milyonlarca insanın salgına yakalandığı, yaşamını yitirdiği ve hayatta kalma mücadelesi verdiği söz konusu salgın, henüz tam olarak nedenleri bilinmese de, sonuçları açısindan bütün bir insanlığa ciddi zararlar vermeye devam etmektedir. Salg1nın ortaya çıkmasıyla birlikte, başta Çin olmak üzere İtalya, İran ve İspanya gibi ülkelerde salgın vakaları ve salgın kaynaklı ölümler hızla artmıştır. Bu ülkeleri daha sonra İngiltere, Almanya, Fransa, Belçika, Hollanda, Amerika Birleşik Devletleri ve Türkiye takip etmiştir. Söz konusu ülkelerin temel özelliği, dünyada koronavirüs salgını sebebiyle en fazla vakanın görülmesi ve en fazla ölümlerin yaşanmasıdır. Salgının küre üzerinde yayılmasıyla birlikte, salgınla mücadele ve salgına bir çözüm üretme yönündeki çabalar da oluşmaya başlamıştır.

Salgın sonuçları itibariyle insan ve toplum yaşamını derinden sarsmıştır. Gündelik yaşamın bütün alanlarına nüfuz eden salgın, hayatı adeta durma noktasına getirmiştir. Toplumsal yaşamda bireylerin birbirleriyle ilişki kurma biçimleri değişmeye başlamıştır. Karantina koşullarına uyum sağlama, fiziksel mesafeler oluşturma, zamanın büyük bir kısmını maske takarak geçirme, aile ve akraba ilişkilerini askıya alma, hijyen koşullarına uygun davranma gibi alışıldık olmayan yeni davranış biçimleri oluşmaya başlamıştır. Çok sayıda işyerinin kapanması, insanların işsiz kalması, geçim sıkıntısının artması, yoksulluğun görünür hale gelmesi, ekonomik daralmanın getirdiği zorluklar, salgının oluşturduğu ekonomik buhranın boyutlarını oluşturmuş̧tur. Salgınla birlikte dijitalleşme hız kazanmaya başlamış, hayatın akışı dijital platformlar üzerinden sürdürülmüş, toplumsal etkileşimler uzaktan yapılmaya başlanmış ve bu yeni yaşam biçimi uzun vadede alışılması gereken bir yaşam biçimini oluşturmuştur.

Toplumsal yaşamı derinden etkileyen salgının neden olduğu sorunların üstesinden gelmek ve salgınla mücadele etmek amacıyla birbirinden farklı yöntemler uygulanmaktadır. Söz konusu yöntemlerden biri de, kuşkusuz sınırlardır. Salgının küresel ölçekte görülmesi sebebiyle, sınırlar, salgının yayılmasını engellemede işlevsel hale gelmiştir. Sınırların etkin bir şekilde kullanılması, esasında salgınla mücadelede her ülkenin kendi imkân ve potansiyelleri dâhilinde mücadele ettiğini, salgının yayılmasını önlemeye 
çalıştığını ve kendi içinde tedbirler aldığını göstermektedir. Dahası, sınırların küresel salgınla mücadeledeki işlevselliği, sınırların önemini, etkisini ve değerini artırmıştır. Ancak COVID-19 salgınıyla birlikte, salgınla mücadelenin ulus-devletler düzleminde yapılması, sınırların bu mücadelede etkin kullanımı (sınırların insan ve araç trafiğine kapatılması gibi), sınırların yeniden düşünülmesini gerektirmiştir. Bu kez sorgulanan sınılar değil, bizatihi küreselleşmenin kendisidir.

COVID-19 salgınıyla birlikte sınırların değişen anlamını ortaya çıkarmak, bu çalışmanın temel amacını oluşturmaktadır. Sonuçlar ve çözümler bağlamında küresel salgın sınırları nasıl etkilemiştir? Salgın öncesi ve salgın sürecinde sınırlara ne tür anlamlar yüklenmiştir? Salgının küresel olması karşısında çözümün ulusal olması sınırlara nasıl yansımıştır? Salgınla mücadelenin ulus-devletler üzerinden yapılması küreselleşmenin sorgulanmasını nasıl etkilemiştir? Sınırlar küresel hastalığın ulusal tedavisinde nasıl bir rol ve işleve sahip olmuştur? Ulus-devletlerin sınırları içerisinde yaşayanlarla dışarısında kalanlar salgın sürecinde hangi kategorik kimlikler üzerinden tanımlanmışlardır? Ulusal izolasyonun sağlanmasında sınırlar nasıl bir etkiye sahip olmuştur? Salgın sürecinde sınırların küresel insan hareketliliği üzerinde ne tür etkileri bulunmaktadır? Küresel salgınla birlikte değişen milliyetçiliği anlamada sınırlar nerede yer almaktadır? Türkiye'nin küresel salgınla mücadelesinde sınırlar nasıl bir işleve sahip olmuştur? Bu ve buna benzer sorular, bu çalışmanın temel sorunsalını oluşturmaktadır. Bu sorunsal çerçevesinde, çalışmada küresel salgınla birlikte sınırların içerdiği anlam haritalarında ne tür değişimlerin yaşandığı anlaşılmaya çalışılmıştır.

\section{Sonuçlar ve Çözümler Bağlamında Küresel Salgın ve Sınırlar}

COVID-19 salgınının küresel ölçekte yayılması, toplumsal yaşamın bütün boyutlarında kendisini göstermiştir. Ekonomiden dine, eğitimden gündelik yaşama, aileden çalışma hayatına, siyasetten medyaya ve hukuka kadar hayatın alanın etkisini altına alan salgın, nedenleri henüz tam olarak bilinmese de, sonuçları itibariyle dünyada milyonlarca insanın ölmesine, hastalığa yakalanmasına ve hayatta kalma mücadelesi vermesine neden olmuştur. Böyle bir küresel sorun karşısında dünya ölçeğinde mücadele verilmekte, her bir mücadelenin yöntemi de birbirinden farklılık göstermektedir. Salgınla mücadelede başvurulan yöntemlerden biri de, sınırların etkin bir biçimde 
kullanılmasıdır. Sorun küresel olsa da, çözümün ulusal olması, bu bağlamda salgınla mücadelede her bir ulus-devletin kendi kendine yeter anlayışıyla mücadelesini sürdürmesi, sınırların artan önemini göstermektedir.

COVID-19 salgınının sınırlarla ilişkisi, salgının sonuçları ve salgınla mücadelede ortaya çıkan çözümler bağlamında görülmektedir. Sonuçları açısından salgın, küresel ölçekte etkisini göstermiş ve bir virüs üzerinden dünyayı teslim almıştır. Her ne kadar salgın Çin'in Vuhan kentinde ortaya çıkmış olsa da, çok kısa bir süre içerisinde bütün dünyayı etkisi altına alarak küresel boyutta etkiler oluşturmuştur. Veysel Bozkurt'un belirttiği gibi, küreselleşme sürecinde dünya daha akışkan hale geldi, bir yerde ortaya çıkan bir mal ya da virüs dünyanın geri kalan kısmına bugüne kadar görülmedik bir hızla ulaşabilmektedir. Başlangıçta Çin'e ait olarak düşünülen bu virüs çok kısa bir sürede bütün dünyanın sorunu oldu (Bozkurt, 2020, s. 134). Salgın küresel ölçekte yaşanmaktadır ve bu yönüyle sınırları aşmakta ve sinırları etkisiz hale getirmektedir. Salgının sinır tanımaması, sınırların varlığını sorgulayan sonuçlar ortaya koymuştur. Salgın karşısında sınırların etkinliğini yitirmesi ve salgının sınır tanımaması, sınırları önemli ölçüde işlevsiz kılmış durumdadır.

Salgının sonuçları kadar salgınla mücadele ve salgına getirilen çözümler de sınırları doğrudan etkilemiştir. Sonuçları açısından salgın sınırları işlevsizleştirirken, çözümler bağlamında salgın sınırları etkin bir biçimde devreye sokarak sınırları daha fazla işlevsel hale getirmiştir. Diğer bir ifadeyle, salgının sonuçları sınırların etkinliği üzerinde olumsuz etkiler ortaya koyarken, salgına yönelik çözüm arayışları sınırlar üzerinde olumlu etkileri oluşturmuştur. Bunun temel sebebi, sorunun küresel, buna karşın çözümün ulusal olmasıdır. Her ne kadar salgın küresel ölçekte ortaya çıkmış olsa da, salgına yönelik çözüm arayışlarının ağırlıklı olarak ulusal ölçekte olduğu göze çarpmaktadır. Çözümün ulusal ölçekte olması, sınırları daha etkin ve görünür hale getirmiştir. Öyle ki, salgının ilk ortaya çıkması ve dünya ölçeğinde yayılmasıyla birlikte, salgına karşı yapılan ilk çözüm ve alınan ilk önlem, sınırları kapatmak olmuştur. Sınırların bütünüyle kapatılması, salg1nın yayılmasını önlemeyi sağladığı gibi, sınırları daha etkin hale getirerek onun önemini daha da artırmıştır. 


\section{Küreselleşme, Ulus-Devlet ve Sınırlar Bağlamında COVID-19 Salgını}

Küreselleşme; gruplar, ülkeler, bölgeler arasında ekonomik, teknolojik, siyasal ve kültürel ilişkilerin artması, karşılıklı olarak daha fazla etkileşimi, sınır tanımaz gelişmelerle milli sınırların zayıflatılması ve bunlara bağlı olarak küresel toplum ve vatandaşlık bilinci geliştiren süreçler, kabuller ve yaptırımlara dair geniş içerikli olarak tanımlanabilir (Karabağ, 2014, s. 133). Bir başka ifadeyle küreselleşme, teknolojik gelişmeler ve serbest ticaret anlay1şının ulusal sınırları engel olmaktan giderek çıkarmasıyla, toplumlararası ilişkilerde ve ekonomik bağımlılıkta görülen artıştan kaynaklanan, sosyal, ekonomik ve siyasi yapıları görülmemiş düzeyde değişime zorlayan bir süreçler bütünüdür (Şahin, 2009, s. 42).

Küreselleşme ve sınırlar arasındaki ilişkiyi küresel salgın öncesi ve sonrası olmak üzere iki farklı bağlamda anlamak gerekir. Küresel salgın öncesi bağlamda küreselleşme, ulusal sınırların ortadan kaldırılması, sınırları yok sayma, sınırötesilik, sınırsızlık, sınırsız dünya fikri gibi çeşitli anlamları içerdiği görülmektedir. Geçmişle kıyaslandığında sınırların küreselleşmeye koşut bir biçimde esnek, geçirgen, akışkan bir yapıya dönüştüğü vurgulanmaktadır. Öyle ki küreselleşmeye ilişkin tanımlamalara yakından bakıldığında, bu tanımların ortak özelliğinin sınırlar üzerinden yapılmış olmasıdır. Küreselleşmeyle ilgili hiçbir tanım yoktur ki, sınırlarla irtibatlı olmasın ya da sinırları konu edinmemiş olsun (Bkz. Giddens, 1994; Bauman, 2006; Robertson, 1999). Küreselleşmeyi sınırlarla ilişkilendirerek yapılan tanımlamaların ağırlıklı yönü, sınırların etkisini yitirdiği yönündedir.

Küresel salgın öncesi dönemde sınılar, küreselleşme açısından anlamını ve işlevini yitirmiş bir pozisyonda yer alırken, küresel salgınla birlikte başlayan yeni dönemde, sınırların küreselleşme açısından öneminin giderek arttı̆̆1 görülmüştür. Küresel salgına karşı mücadelede sınırlar, en önemli silahlardan biri olarak düşünülmüş ve böylece salgının yayılmasını engelleyecek bir işleve sahip olmuştur. Salgın her ne kadar küresel ölçekte ortaya çıkmış olsa da, salgınla mücadelenin ulusal olması sınırların önemini daha fazla ön plana çıkarmıştır. Bu çerçevede, küresel salgına karşı mücadelede ulus-devletler sınırları aracılı̆̆ıyla önlemlerini almaya başlamış ve sınırlar üzerinden salgına dur diyebilmeye çalışmıştır. Sınırlar üzerinden salgını önlemeye koşut bir biçimde ulus-devletlerin küreselleşme karşısındaki gücü ve etkisinin büyüdüğünü söylemek yanlış olmayacaktır. Salgın öncesinde 
ulus-devletlerin egemenliği küreselleşme karşısında belirli bir biçimde gerilemiştir. Michael Hardt ve Antonio Negri'ye göre, küreselleşme süreçlerine paralel olarak ulus-devlet egemenliğinin, hala etkili olsa da, giderek gerilediği doğrudur. Üretim ve mübadelenin asli unsurları -para, teknoloji, insanlar ve metalar- sinırları giderek daha kolay geçiyor; dolayısıyla ulus-devlet bu akışı düzenleme gücünü ve ekonomi üzerindeki otoritesini günden güne yitiriyor. En baskıcı ulus-devletler bile artık, bırakın dışarıyı, kendi sınırları içinde bile en üstün ve egemen otoriteler olarak düşünülmemelidir (Hardt ve Negri, 2012, s. 15). Küresel salgınla birlikte gücünü artıran ulus-devletler, günümüz gelişmeleri ışığında temel bir aktör olarak konumunu korumuş ve sürdürmüştür. Küreselleşme sürecinde egemenlik alanları üzerindeki kontrol gücünü büyük ölçüde yitirdiği kabul edilen ulus-devletlerin, salgınla birlikte, özellikle sınırları üzerindeki denetim, kısıtlama ve kontrol haklarının kullanımı konusundaki uygulamalarıyla, temel birer aktör olarak tekrar ortaya çıktıkları söylenebilir.

\section{Salgına "Sınır"lı Çözüm: Küresel Hastalığa Ulusal Tedavi}

COVID-19 salgını kuşkusuz küresel ölçekte bir salgındır. Bu salgın milyonlarca insanı ölüme terk ettiği gibi, yine milyonlarca insanın hastalığa yakalanmasına da sebebiyet vermiştir. Küresel bir hastalık olan salgın kısa sürede tüm toplumları etkisi almış ve dünya ölçeğinde görülen bu hastalığa karşı adeta seferberlik ilan edilmiştir. Hastalığı ortadan kaldıracak ve hastaları tedavi edecek birbirinden farklı yönteme başvurulmaktadır. Küresel bir hastalık olarak beliren salgınına karşı en önemli tedavi yöntemlerin başında ulusal tedavi gelmektedir. Tedavinin ulusal olması, her ulus-devletin kendi tedavi yöntemini kendisinin belirlemesine sebep olmuştur.

Küresel hastalığı ulusal ölçekte tedavi etmek, sınırlar vasıtasıyla salgınla mücadeleyi gerekli kılmaktadır. Tedavinin ulusal olması, devletlerin ve toplumların ulusal kaynakları seferber ederek salgınla baş edebilmesi anlamını taşımaktadır. Bu durum esasında küresel salgın karşısında ulusalcı politikaları belirgin bir biçimde ön plana çıkarmıştır. Türkiye Bilimler Akademisi tarafından 2020 yılı Nisan ayında yayınlanan COVID-19 Pandemi Değerlendirme Raporu'na göre, salgın riski temel olarak ulusalcı politikaların giderek daha fazla görülmesi de dâhil olmak üzere siyasi ve sosyal faktörler nedeniyle artmaktadır. Salgın planlaması ve desteği sağlayan ulusla- 
rarası kuruluşlara verilen destek ve kaynaklar azalmaktadır. Ayrıca, daha ulusalcı bir yönelim ülkelerin yerel çıkarları gözeten ve muhtemelen küresel çıkarlara hizmet etmeyen tedbirler alma riskini artırmaktadır. Bu tedbirlerden bazıları şöyledir: küresel sağlık sorunlarına müdahale için kaynakların yurt dışına tahsis edilmesi konusunda isteksizlik, numune paylaşımı gibi sınır ötesi araştırma girişimlerinde iş birliği yapma isteksizliği, insanların ve ticaretin hareketini engellemek için atılan adımlardır (TÜBA Raporu, 2020, s. 29).

Küresel hastalığa yönelik ulusal tedaviye ilişkin söz konusu gelişmelerin yanı sıra sınırlar da bahsi geçen tedavinin önemli bir boyutunu oluşturmaktadır. Çünkü ulus-devlet sınırları, nüfusun salgına karşı korunmasından salgının yayılmasının engellenmesine, sınırlar içerisindeki salgının sınırların dışına taşmasını engellemesinden sınırların dışındaki salgının sınırların içerisine nüfuz etmesine kadar her anlamda küresel salgına karşı korumanın ve korunmanın temel araçlarından biri olmuştur. Diğer bir ifadeyle, sınırlar salgın hastalığın sınırların içerisinde nüfuz etmesini ya da sınırlar içerisindeki salgın hastalığın sınırların dışına bulaşmasını önlemiştir. Bu bağlamda, ulus-devletler salgınla mücadeleyi diğer alanların yanı sıra sınırlar üzerinden de gerçekleştirmesi, sınırların değerini, önemini ve işlevlerini artırmış ve sınırlar tedavinin temel araçlarından birine dönüşmüştür.

Sınırlar, her ne kadar küresel hastalığın tedavisinde etkili olsa da, ortaya koyduğu tedavi, salgınla mücadeleye kısıtlı düzeyde bir katkı sunmuştur. Diğer bir ifadeyle, küresel hastalığın tedavisinde söz sahibi olan sınırlar, salgının yayılmasını önlemede sınırlı bir çözüm sunabilmiş, bu çözümünü de sınırlar üzerinden gerçekleştirebilmiştir. Sınırların salgını engellemedeki etkisi sınırlı düzeyde olmuştur. Çünkü her ne kadar ulusal sınırlar üzerinden salgına karşı konulsa da, salgın belirli ölçülerde sınır tanımayıp küre üzerinde yayılımını sürdürmüştür. Florian Biber'ın da belirttiği gibi, COVID-19'un sınırların ötesinde yayılması, sınırların kapatılması ve uluslararası hava trafiğinin çökmesi gibi son derece baskıcı önlemlerin bile hastalığın yayılmasını durduramadığını gösterdi (Bieber, 2020, s. 8). Salgının sınır tanımaması karşısında sınırlar, salgını kısıtlı bir biçimde durdurabilmiş ve salgının bütünüyle yayılmasını kontrol altına almıştır. Bu yönüyle sınırlar, küresel hastalığın tedavisinde sınırlı da olsa bir çözüm üretmiştir. 


\section{Salgını "Sınır"la(ndır)mak: Hijyenik, Steril, Sağlıklı Versus Kirli, Virüs- lü, Hastalıklı}

Sınırların küresel hastalığa karşı ulusal bir tedavinin temel aracı olmasının somut yansımaları, özellikle salgının sınırlar üzerinden sınırlandırılmasında görülmektedir. Sınırlar küresel salgınla mücadelede toplumu korumanın temel araçlarından birini oluşturmaktadır. Toplumu sınırlar vasıtasıyla korumak, toplumsalın sınırlar üzerinden bir mekânda inşasını sağlamaktır. Söz konusu mekân, ulus-devlet mekânı olup, bu mekânda yaşayanların korunması için salgının sınırlandırılması gerekmektedir. Küresel salgına karşı sınırlar, toplumsalı temelde iki farklı mekâna ayırarak bu mekânlar üzerinden toplumsalı yeniden kurgulamış ve mekânlar arası farklılaşmalar yoluyla toplumu koruma altına almaya çalışmıştır.

Toplumsalın mekânı, esasında ulus-devletin mekânıdır. Bu bağlamda, biz ile onlar, içerisi ile dışarı, bu taraf ile o taraf, burası ile karşısı, yerli ile yabancı gibi ikili kategoriler, sınırların ulus-devletlerin mekânını yeniden planlama ve organize etmesinin bir ürünüdür (Bkz. Durgun, 2011; Hardt ve Negri, 2012; Bauman, 2013). Bu ikili kategoriler üzerinden sınırlar, küresel salgın karşısında toplumsalı korunaklı bir mekân haline getirmektedir. Buna göre, ulus-devlet sınırları içerisinde kalan mekan, sınırların dışarısında kalan mekan karşısında daha hijyenik, daha steril, daha sağlıklı ve daha temiz olanı temsil etmektedir. Ulus-devletin mekânı, virüsün bulaştırılmadığı ya da virüsten arındırılmış olanla bir ve eşdeğer kabul edilmektedir. Bu anlamda sınırların içerisi, hijyenik, steril, temiz, virüssüz, sağlıklı gibi kavramlarla tanımlanmaktadır. Ulus-devlet sınırları dışında kalan mekan, hijyenik olmayan, sağlıksız, virüslü ve kirli olanı temsil etmektedir. Sınırın dışındakiler, kirli olanla, hastalıklı olanla ve virüslü olanla bir ve eşdeğer kabul etmektedir. Söz konusu anlayış, sınırların içerisini sağlıklı, dışarısını hastalıklı olarak kodlamaktadır.

Küresel salgın karşısında ulus-devletler, sınırları içerisinde kalan yurttaşları adına steril bir yaşam alanı sunduğunu, bu alanın küresel salgınla birlikte dışarıdan gelenler tarafından işgal edilmeye çalışıldığını, kendisinin de bu dışarıdan gelenlere karşı sınırları kapatarak salgınla mücadelesini sürdürdüğünü vurgulamaktadır. Sınırları kapatmak, ulus-devletlerin steril olarak deklare ettiği mekanı sınırın dışında yer alan risk ve tehditlere karşı koruması anlamını taşımaktadır. Her ne kadar, salgının ulus-devletlerin daha da 
içe kapanmasına yol açmasının mümkün olduğu (Bkz. Woods, Schertzer, Greenfeld, Hughes ve Miller-Idriss, 2020) vurgulansa da, ulus-devletler bu süreçte içe kapanmak yerine küreselleşmeyi değiştirip dönüştürmeye çalışmaktadır. Bu bağlamda, sınırların kapatılması, ulus-devletlerin içe kapanması olarak düşünülse de, esasında bu kapatılmayı içe kapanmak yerine küreselleşmeyi dönüştürmenin bir ifadesi olarak okumak yerinde olacaktır. Hâlihazırda küreselleşme sorgulanırken (Bkz. Hirst ve Thampson, 2003), salgın bu sorgulamaya yeni boyutlar kazandırmıştır. Sınırları kapatmak bütünüyle içe kapanmak anlamı taşımadığı gibi, sınırları, küreselleşme karşıtı uygulamaların tetikleyicisi olarak düşünmek de eksik ve yanlış olacaktır. Daha ziyade, sinırlar, küresel gelişmelere farklı biçim ve içeriklerde tepkiler vermekte ve karşılıklı olarak birbirlerini dönüştürmektedirler. Diğer bir ifadeyle, sinırlar, salt küreselleşmenin dönüştürdüğü edilgen nesneler değil, aksine küreselleşmeyi bizzat dönüştüren ve bu anlamda küresel gelişmeler üzerinde etki edecek ve farklı sonuçlar ortaya koyacak potansiyellere sahiptir. Zira koronavirüs salgınıyla birlikte sınırların etkililiği daha fazla ön plana çıkmakta ve sınırların sahip olduğu önem daha çok artmaktadır. Sınırların etki ve önemi, onların küresel salgınla mücadelede oynadıkları rol ve taşıdıkları işlevlerle görülmüştür.

\section{Bir Ulusal İzolasyon Aracı Olarak Sınırlar}

İzolasyon kavramı yalitım anlamına gelmektedir (Bkz. TDK). Sosyal izolasyon, sosyal durumun gelişmesinde bir risk faktörü olarak düşünülmektedir. Sosyal izolasyonun temel nedeni, uygun sosyal ilişkilerin olmamasıdır. Yaşam koşullarındaki ilerleme, artan otomobil sayısı, artan bürokratikleşme ve diğer sosyal güçlerin karmaşık bir matrisi, çağdaş insanı parçalamaya, itaatsizliğe ve küçültmeye hizmet etmekte ve böylece onu kendisinin bir parçası olduğu toplumdan izole etmektedir. Sosyal olarak izole edilmiş birey, sosyo-politik olaylar üzerinde çok az etkisi veya kontrolü olmadığını hissettiği ve durumunu değiştirmeye tabi olduğunu iddia edemeyeceğini hisseden kişi olarak tanımlanabilir (Masoom, 2016, s. 241). Bu bağlamda, sosyal izolasyon, bireyin kendisini toplumsal yaşamdan yalıtarak uzaklaştırmasıdır. Sosyal izolasyon kavramı, sosyolojideki yaygın kavramlardan birini oluşturan sosyalizasyon kavramına taban tabana zit bir kavramdır. Sosyalizasyon, bireyin içinde yer aldığı toplumsal kültürü deneyimlemesi, toplumsal ya- 
şama katılması, sosyal ilişki ve etkileşim tarzlarını şekillendirmesi ve toplumsal statü ve rollerini icra etmesi olarak tanımlanırken, sosyal izolasyon, bireyin toplumsal yaşamdan kendisini ayrıştırarak eve kapatması, bu anlamda kendi toplumsal eylemliliğini kısıtlamasıdır. Sosyal izolasyon, salgın hastalıklar döneminde uygulanan yollardan biri olup, salgın hastalığa bağlı olarak yerel, ulusal, bölgesel ya da küresel boyutta görülmektedir.

COVID-19 salgınıla birlikte, salgınla mücadelede uygulanan yollardan biri de, sosyal izolasyondur. Bireyler, fiziksel mesafelerini korumak amaciyla sosyal izolasyona başvurmakta ve bu sayede diğer bireylerle temas düzeyini en düşük seviyeye çekmektedir. Bu konuda "evdekal" ve "hayat eve sığar" uygulamaları, salgın sürecinde sosyal izolasyonu sağlamaya dönük önde gelen uygulamalardan biri olmuştur. Bireyler kendilerini evlerine kapatarak ve evde kalarak kendisini toplumdan izole ederek salgının daha fazla kitleye yayılmasını engellemektedir. Salgının yayılması özellikle kalabalık ortamlarda daha hızlı olduğundan, bireylerden beklenen, kalabalıklar da dahil olmak üzere, her türlü sosyal yığınlardan uzak durmaları, evlerinden dışarıya çıkmamaları ve sosyal izolasyon şartlarına uyum sağlamalarıdir.

Sosyal izolasyon, her ne kadar COVID-19 salgını bağlamında bireylerin kendilerini izole etmesi şeklinde tezahür etse de, esasında salgının sonuçları göz önüne alındığında izolasyonunun boyutunun salt bireyler düzeyinde kalmadığı, daha ziyade toplumlar, dolayısıyla uluslar/ulus-devletler düzeyinde gerçekleştiği görülmektedir. Ulusal izolasyon, her bir ulus-devletin kendini dünyadaki diğer ulus-devletlerden yalıtması, onlarla temas kurmaması ve ulusal mekanda kendisini izole etmesidir. Ulus-devletlerin söz konusu izolasyonu ise, ancak ulusal sınırlar bağlamında gerçekleşebilmektedir. Bu anlamda sınırlar, küresel salgın karşısında ulusal izolasyonu sağlamanın temel araçlarındandır. Sınırlar vasıtasıyla her bir ulus-devlet kendini uluslararası ve küresel etkileşimden izole ederek salgınla mücadelesini sürdürmektedir. Bu bağlamda, ulusal sınırlar içerisinde yer alan mekan, ulusal kimliğin üyelerince izolasyonunun gerçekleştiği, dolayısıyla, her bir yurttaşın kendi yurdunda kaldığı mekandır. Ulusal izolasyonda, "evdekal" uygulamasının yerini "yurttakal" uygulamasına bıraktı̆̆ını söylemek mümkündür. Ya da ulusal izolasyonda "hayat eve sığar" uygulaması yerini "hayat yurda sığar" uygulamasına bıraktığını söylemek yanlış olmayacaktır. Ulusal izolasyonun aracı olan sınırlar, salgınla mücadelede önemli katk1- 
lar sunarak dünyada ulus-devletlerin kendilerini izole etmelerini sağlamıştır. Bu açıdan "yurtta izolasyon, cihanda izolasyon" şeklindeki bir söylem, kuşkusuz küresel salgın koşullarında ulusal izolasyonu en iyi şekilde ifade etmektedir.

\section{Küresel Salgın, Sınırlar ve Göçler}

Geçmişle kıyaslandığında günümüzde göçler hiç olmadığı kadar artmıştır. Artan göçler aynı zamanda hızlanmaya, yaygınlaşmaya ve değişmeye başlamıştır. Küreselleşmeyle birlikte göçlerin yönü, mahiyeti, çeşitliliği, farklılığ1 ve değişikliliği belirgin hale gelmiştir. Günümüz dünyasını birer göçler çağ 1 olarak ifade eden yaklaşımlar görülmektedir (Bkz. Castles ve Miller, 2008). Uluslararası göçlerin küresel bir boyut kazandığı, ülkelerin aynı anda hem göç alan hem de göç veren bir konuma ulaştığ 1 ve göçlerin nedenleri ve sonuçları itibariyle bütün toplumları etkilediği göçler çağında, insan hareketliliği hiç olmadığı kadar hız kazanmıştır. Ulaşım ve iletişim teknolojilerinin de artan etkileri bağlamında göçlerin hızlanması, her ne kadar olumlu anlamları çağrıştırsa da, COVID-19 salgını üzerinden bakıldığında bu hızın olumsuz sonuçları ortaya çıkardığı görünmektedir. Çünkü salgının insan hareketliliğiyle birlikte yayılması, göç hareketlerinin salgının yayılmasında doğrudan etkileri olduğunu işaret etmektedir. Salgın ve göç ilişkisinde, burada vurgulanması gereken husus şudur: salgının yayılması, bir insan hareketliliğinin ürünüdür. Göçler de birer insan hareketliliğidir, dolayısıyla da göçlerle de salgının yayılma, virüsün bulaşma ihtimali bulunmaktadır. Bu bakımdan her türlü insan hareketliliğine getirilen kısıtlamalar, göç hareketliliğini de doğrudan etkilemektedir.

Sınırların küresel salgına karşı mücadeledeki etkisi, küreselleşmiş insan hareketliliğini denetleme, düzenleme ve engelleme işlevine sahip olmasıdır. Küresel insan hareketliliğinin sınırları aşan boyutlarda olması ve salgının da bu hareketlilik üzerinden yayılması, sınırların sözü edilen işlevlerinin önemini göstermesi bakımından önemlidir. Küresel salgın döneminde en çok tartışlan ve çözüm üretmeye çalışılan konuların başında, yerel, ulusal, bölgesel ve küresel düzeyde insan hareketliliğini kontrol etmek, bu anlamda toplumsal ilişki ve etkileşim biçimlerini düzenlemek olmuştur. Sokağa çlkma kısıtlamalarından, turistik ziyaretlere, gösteri, toplantı, miting ve yürüyüşlerden toplu taşımaya, kahvehanelerden uluslararası ticarete, umre ve 
hac ziyaretlerinden uzaktan eğitime kadar insan ve toplum yaşamının bütün alanlarına nüfuz eden salgınla başa çıkabilmek zor olduğundan, bu zorluğu aşabilmek için her türlü yola başvurulmaktadır. İnsanlığı tehdit eden, sonuçları itibariyle milyonlarca insanın ölümüne neden olan, yine milyonlarca insanın tedavisinin devam ettiği ve yeni hasta sayılarının artarak devam ettiği bu zorlu süreçte, ulus-devletler açısından aslolan sınırlar vasıtasıyla küresel ve uluslararası göç hareketlerini kısıtlamak, kontrol altına almak ve denetlemektir.

Çin'in bir kentinde ortaya çıkan ve daha sonra dünyanın geri kalan k1sımlarına yayılan salgın, nihai olarak küresel insan hareketliliğinin etkisi altında yayılmıştır. Bu yayılmadan göçmenler de nasibini doğrudan almıştır. Göçmenler, bu süreçte hastalığın taşıyıcıları olarak görülmeye başlanmış, bu sebeple, salgınla mücadeledeki en riskli gruplardan biri olarak görülmüştür. Küresel salgın şartlarında göçmenler hastalıkla bir tutularak salgının daha geniş kitlelere ulaşmasından sorumlu tutulmuşlardır. İbrahim Sirkeci ve Murat Yüceşahin, COVID-19 salgının yayılımında göçün rolünü üç modelde test etmişlerdir. Buna göre, Model 1'de, belirli bir hedef ülkeye Çin'den gelen her ek göçmenin, COVID-19 vakalarının sayısında 6,9'luk bir artışa neden olduğu ortaya çıkmıştır. Model 2, bir hedef ülkeden Çin'e gitmiş olan her ek göçmen, o ülkede 6,73 oranında daha fazla COVID-19 vakası bulunduğunu göstermiştir. Model 3 ise insan hareketliliğindeki her bir birim artışın, 6,52 daha fazla COVID-19 vakasına yol açtığını ortaya koymuştur. Bu nedenle, ülkelerde bulunan sadece Çinli göçmenlerin sayısının değil, daha çok, her iki yönde insan hareketliliğinin, diğer bir ifadeyle Çin'deki uluslararası göçmenler de dâhil olmak üzere, Çin ile irtibatlı tüm ülkelerin salgın coğrafyasına dâhil oldukları anlaşılmaktadır (Sirkeci ve Yüceşahin, 2020, s. 18-19). Söz konusu modeller, göçlerin salgının yayılmasinda etkili olduklarını göstermektedir.

Salgınla birlikte uygulanan karantina, seyahat yasakları ve sosyal mesafe önlemleri, göçmenlerin farklı kentlere ya da ülkelere göç etmesini engellediği gibi, salgınla birlikte geriye göçleri de virüsün yayılmasını engelleme çabaları kapsamında sekteye uğramıştır. İlhan Zeynep Karakılıç ve Besim Can Zırh'a göre, COVID-19 küresel salgını göçmenler açısından üç temel duruma yol açmıştır: (a) Geriye Dönüş: Küresel duraklamayla birlikte günlük geçimlik imkânları ve/veya belirli hizmetlere erişimi kaybeden göçmenler hâlihazırda coğrafi hareketliliklerini belirli bir dönem için tamamlamış 
olsalar da acil ve güvencesiz bir şekilde tekrar (geriye doğru) hareketliliğe başlamak zorunda kaldılar. (b) Arada Kalma: Çeşitli nedenlerle hareket halinde, henüz istikametlerine varmamış olan ya da bulundukları yerlerde işleri kaybettikleri için geri dönmek isteyen göçmenlerin sınırların kapanmasıyla gelir ve hizmet erişimi olmadan hareketsiz kalmaları ikinci temel durumu oluşturuyor. (c) Katmanlı Sıkışma: Göçmenlerin hâlihazırda mülteci olarak bulundukları yerellerde karantina uygulamalarıyla birlikte süreç içinde geliştirdikleri (en)formel gelir kaynakları, dayanışma ağları ve çeşitli hizmetlere erişimlerinin kısıtlanması nedeniyle içinde bulundukları bekleme halinin derinleşmesi son temel durumu oluşturuyor (Karakılıç ve Zırh, 2020, s. 4).

Salgın, ulus-devletlere göçmenler üzerinde tasarrufta bulunmanın koşullarını sunmuştur. Salgınla birlikte ulus-devletlerin göçmenler üzerinde hemen her türlü tasarrufta bulunmaları kabul edilebilir görülmeye başlanmıştır. Salgın öncesinde ulus-devletlerin göçmenler üzerindeki meşruiyeti tartışılır durumdayken, salgınla birlikte meşruiyeti tartışılır olmaktan çıkmaya başlamıştır. Çünkü göçmenler, özellikle de düzensiz göçmenler, salgının taşıyıcıları olarak kodlanmakta, bu anlamda potansiyel risk ve tehditleri gittikleri ülkelere götürenler olarak görülmektedir. Bu bakış açısı, esasında bir tür damgalanma biçimidir. Göçmenlerin hastalıklı olarak damgalanması ve virüsün taşıyıcıları olarak işaret edilmeleri, onların toplumdan dışlanmalarına, göç ettikleri ülkelerde ötekileştirilmelerine ve kriminalize edilmelerine sebebiyet vermektedir. Göçmenlerin damgalanması, dışlanması ve ötekileştirilmesi, ev sahibi toplumun gözünde göçmen algısını değiştirmeye başlamış, bu da onların toplumsal uyumunu zorlaştırdığı gibi, toplumsal uyum konusundaki birikimini de ortadan kaldırmıştır.

\section{Küresel Salgın Koşullarında Milliyetçilik ve Sınırlar}

Sınırlar üzerinden küresel salgına çare bulmak, salgının yayılmasını önlemesinin ötesinde milliyetçiliğin görünür olması anlamını içermektedir. Çünkü milliyetçilik sınırlar üzerinden örgütlenmekte ve sınıllar aracılığıyla bir ulusal kimlik inşa etmektedir. Sınırları kapatmak, esasında var olan s1nırları yeniden inşa etmek anlamı taşıdığından, sınırların inşası ulusal kimliklerin inşasıdır. Sezgi Durgun'un da altını çizdiği gibi, 18. ve 19. yüzyıllarda gelişen ve yükselen ulus-devlet ideolojisi coğrafi bağlamı sınırlandırmak- 
la kalmamış, beşeri ve fiziksel zemin üzerinde homojenleştirici bir rol oynamıştır. Mekân, kolektif aidiyetin ortak zemini haline gelmiştir. Bu çerçevede ulusal tarih ve coğrafya anlatıları kurgulanmış, sadece fiziksel anlamda değil, toplumsal kimlik anlamında da içerisi ve dışarısı tanımlanmıştır. Nerenin içerisi nerenin dışarısı olacağını belirleyen faktörler (etnisite, kültür, din, dil, ırk, coğrafya gibi), farklı ulusçuluklarda farklı özellikler göstermektedir (Durgun, 2011, s. 14-15). Milliyetçilik, sinırlar üzerinden ulusal kimliği inşa ederken, içerisi-dışarısı, burası-orası, biz-onlar, yerli-yabancı gibi kategorik bileşenler oluşturmakta ve bu bileşenleri sinırlar temelinde düzenlemektedir. Ulus-devletlerin sınırları, milliyetçiliğin ulusal düzlemde bir kimlik inşa ettiğini, sınırların ulusal kimliğin sembolik mekânı olduğu ve sınırlar üzerinden ikili kategoriler vasıtasıyla kimlik inşasını gerçekleştirdiği görülmektedir.

Küresel salgın karşısında sınırlar vasıtasıyla sözü edilen ikilikler oluşturularak, ulus-devletlerin sınırları içerisinde yer alanların sağlıklı, sınırların dışarısında yer alanların hastalıklı oldukları, sınırların içerisinde yer alan biz kimliğinin temiz, sınırların dışarısında yer alan onlar kimliğinin kirli oldukları ve sınırların içerisinde yer alan yerlilerin salgından arındırılmış ve sınırların dışarısında yer alan yabancıların ise salgının bulaştırıcıları oldukları vurgulanmıştır. Küresel salgın karşısında ulus-devlet sınırlarının içerisinin sağlıklı dışarısının hastalıklı, içerisinin temiz dışarısının kirli, içerisinin virüsten arınmış dışarısının virüslü olarak kodlanması, sıradan bir kategorizasyonunun ötesinde, ulus-devletlerin milliyetçiliğinin salgın üzerinden nasıl tezahür ettiğinin göstergesidir. Ulus-devletlerin biz olanı sağlıklı, temiz, virüsten arınmış gösterirken sınırların dışarısında yer alan ötekileri hastalıklı, kirli ve virüslü olarak göstermesi, esasında sınırların dışarısında yer alan ötekinin bizim gibi olamayacağının, öteki karşısında bizden olanların değerli ve üstün olduğunun ve ötekilerin bizden olanlardan daha aşağ1da bir yerlerde olduğunu göstermektedir, ki bu da kuşkusuz milliyetçiliğinin en belirgin halidir. Bu sayede ulus-devletler, sinırları üzerinden kendi milliyetçi kimliğinin inşasını sağlamaktadır. Bu şekilde küresel salgın karşısında milliyetçiliğin yükselişte olduğu, sınırların da bu yükselişten payına düşeni aldığı görülmüştür.

Küresel salgınının tüm dünyada yayılmasıyla birlikte, her ülke kendi imkân ve potansiyelleri ölçüsünde çözümler üretmeye başlamıştır. Virüsün tüm insanları ve toplumları esir almasına koşut olarak, bu virüsten kurtul- 
mak amaciyla ulus-devletler arasında kıyasıya bir mücadele sürmekte ve bu mücadele milliyetçiliği palazlandıran ve perçinleyen boyutlar ortaya koymaktadır. Ulusal düzeydeki çözüm arayışlarından biri de, salgını ortadan kaldıracak aşının bulunmasıdır. Aşının bulunması meselesi, salt bir hastal1ğın ortadan kaldırılması değil, ulus-devletlerin birbiriyle yarıştıkları bir boyutu da içermektedir. Aşının bulunması üzerinden başlayan ve ulusdevletlerin birbiriyle yarış içerisinde olduğu bu dönem, söz konusu sebeplerden ötürü milliyetçilik tartışmalarının öne çıktığı bir dönem olmuştur. Her ne kadar COVID-19 salgınıyla birlikte ulus-devletin ve milliyetçiliğin yükseleceği yönündeki açıklamalara itibar edilmemesi gerektiğini belirtenler (Bkz. Buçukcu, 2020) olsa da, bu salgını milliyetçiliğin sessiz yükselişi olarak değerlendirenler (Bkz. Vogel, 2020) de bulunmaktadır. Aşının bulunması, milliyetçiliğin yeniden dirilmesini değil, daha ziyade hâlihazırda yeniden dirilmiş milliyetçiliğin yeni boyutlarda, farklı görünümlerde ve değişik biçimlerde görünür hale geldiğini göstermektedir. Aşının bulunması edimi, milliyetçiliği koşullandıran, potansiyellerini harekete geçiren, ortak bir amaç doğrultusunda kitleleri konsolide eden, başka milliyetçilikler karşısındaki gücünü gösteren bir düzlemi içermektedir. Aşıyı bulmayı hedefleyen ulus-devletleri harekete geçiren milliyetçilik, sadece ulus-devletlerin kurulmasında değil, kurulduktan sonra da onlar üzerinde etkilerini sürdüren, onları hareketlendiren, onlara bir toplumsal ve siyasal ruh aşılayan ve üyelerini aynı amaç doğrultusunda bir araya getiren bir harekettir. Bu yeni süreçte milliyetçilik, "Aşı milliyetçiliği" (Bkz. Daoudi, 2020), "Covid milliyetçiliği” (Bkz. Juergensmeyer, 2020), "Corona milliyetçiliği (Coronationalism)" (Bkz. Özkırıml, 2020) gibi farklı isimlerle tanımlanmıştır. Milliyetçiliğin belirli bir "etni" temelinde inşa olduğu göz önüne alındığında, bu yeni milliyetçilik isimlerinin belirli bir etniye dayanmadığı, buna karşın salgının ismi üzerinden bir milliyetçilik tanımının yapıldığı görülmektedir.

Aşının bulunması kadar bulunan aşının ülkelere paylaştırılması da aşı milliyetçiliğinin bir başka boyutunu oluşturmaktadır. Çünkü bulunan aşıya sahip olabilmek için ülkelerin bu aşı için ayırdıkları bütçeler ve yaptıkları anlaşmalar, hangi ülkenin daha fazla aşıya sahip olabileceği, hangi ülkenin yeterince aşıya sahip olamayacağı meselesi, aşı milliyetçiliğini kuvvetlendiren gelişmelerdir. Ayrıca aşının bulunması ve bulunan aşının paylaşılması, ulus-devletler arasındaki güç mücadelesine de ışık tutmaktadır. Salma Daoudi'ye göre küresel halk sağlığının parçalanmasının ve sağlık kaosunun 
ortasında çok taraflılı̆̆ın aşınmasının bir kanıtı olarak, aşı milliyetçiliği sınırlı üretim dozlarını tekeline almak için öncelik hakları yarışı - aşılara erişimi siyasallaştırmakla tehdit ediyor. Etik kaygılara ek olarak, bu milliyetçi yaklaşım sağlık ve sosyo-ekonomik eşitsizlikleri besleyerek gelişmekte olan ülkelere zarar verirken, aynı zamanda herkesin sağlık güvenliğini de tehdit etmektedir. Zamana, başkalarına ve doğaya karşı bu yarış, yeni bir milliyetçilik biçimine yol açtı: aşı milliyetçiliği. Ortaya çıkardığı etik kaygılara ek olarak, bu yarışta yer alan laboratuvarlarla önceden anlaşmalara sahip devletler tarafından güvence altına alınan tercihli erişim, yalnızca daha s1nırlı kaynaklara sahip devletler için değil, aynı zamanda herkesin sağlık güvenliği için de zararlıdır (Daoudi, 2020, s. 1-3). Aşıyla ilgili şu ana dek Almanya, Rusya ve Çin'den somut adımlar gelirken, diğer ülkelerin de bu konuda belirli bir mesafe kat etmişlerdir. Almanya ve Amerika Birleşik Devletleri başta olmak üzere Batılı ülkeler, Çin, Rusya, Japonya ve Türkiye gibi ülkeler, aşı üzerinden kendi güçlerini ortaya koyabilme mücadelesi içerindedir.

\section{“Biz Bize Yeteriz Türkiyem": Türkiye'de Salgın, Milliyetçilik ve Sınırlar}

Milliyetçiliğin salgınla birlikte artan etkisi, salt aşının bulunması, dağıtılması ya da aşı karşıtllğ üzerinden değil, salgınla mücadelede aynı zamanda toplumların dayanışma, örgütlenme ve mücadele biçimlerinde de görülmektedir. Her ülke, her devlet, her toplum kendi kendine yeter şiarıly salgına çözümler üretmekte ve salgına karşı önlemlerini kendi potansiyelleri ve imkânları ölçüsünde almaktadır. Ortaya koyulan yaklaşımlar ve öne sürülen çözümler, salgının küreselliği karşısında çözümün ulus-devletler temelinde şekilleneceği yönünde olmuştur. Diğer bir ifadeyle, küresel salgın karşısındaki ana reçete, ulus-devlet temelinde çözümler üretmektir. Zira daha önce de vurgulandığı gibi, hastalık küresel olsa da, tedavisi ulusaldır.

Milliyetçiliğin yükselişi, ulus-devletlerin birbiriyle karşlaştırılmasında ve birbirleriyle yarışmasında doğrudan gözlemlenebilmektedir. Salgına karşı mücadelelerin ulusal ölçekte yapılması, her bir ulus-devletin birbiriyle karşılaştırılmasına neden olmuş ve bu karşılaştırma aralarındaki yarışma ve rekabeti artırmıştır. Bu durum, milliyetçiliği görünür kılmış ve salgınla mücadelede milliyetçilik, ulus toplumların örgütlenmesinde etkili olmuştur. Hatta imkân ve potansiyeller ölçüsünde diğer ülkelere yapılan ulusal yar- 
dımlar, hem rekabeti artırmış hem de milliyetçilik politikalarına ivme kazandırmıştır. Salgın hastalığının tedavisine yönelik ulusal önlemler ve çözüm pratikleri, ulus-devletlerin birbiriyle rekabetini ortaya koymuş, bu rekabet beraberinde milliyetçiliğin yükselmesini getirmiştir. Milliyetçiliğin yükselişi, salgın karşısında sınırlar üzerinden alınan ulusal önlemlerle, özellikle de sınırların kapatılmasıyla eşgüdümlü bir biçimde gerçekleşmiştir.

Küresel salgınla baş etmede ve virüse karşı topyekûn toplumsal mücadelede milliyetçilik, toplumun motivasyon kaynağına dönüşmüştür. Bireysel ve toplumsal düzeyde mücadeleye rengini veren milliyetçiliğin etkisini ulusal ve uluslararası ölçekte değerlendirmek mümkündür. Ulusal ölçekte toplumlar kendi imkân ve potansiyelleri doğrultusunda mücadelesini ortaya koyarken, uluslararası ölçekte toplumlar diğer toplumlara yardım ederek ve onların mücadelelerine omuz vererek sözü edilen mücadeleyi farklı boyutlarda göstermiştir. Türkiye'nin koronavirüs salgınına karşı vermiş olduğu mücadeleyi sözü edilen bağlamda düşünmek gerekmektedir. Türkiye, dünya ölçeğinde virüse karşı mücadelede çok sayıda ülkeyle karşılaştırıldığında önemli başarılar ortaya koymuştur. Salgınla mücadele sürecinde Türkiye, Cumhurbaşkanı Recep Tayyip Erdoğan liderliğinde, "Biz Bize Yeteriz Türkiyem" adlı bir dayanışma kampanyası başlatmıştır. Bu kampanya, küresel salgın koşullarında Türkiye'nin ortaya koymuş olduğu bir milli dayanışma kampanyasıdır. Söz konusu kampanyanın temel amacı, salgından etkilenen toplumun dezavantajlı kesimlerine destek sunmaktır. Düzenlenen kampanya çerçevesinde Aile, Çalışma ve Sosyal Hizmetler Bakanlı̆̆1 tarafından yapılan bağışlar toplanmış ve salgın sürecinde ihtiyaç sahibi vatandaşlara dağıtılmıştır. Sözü edilen kampanya, Türkiye'nin salgına karşı mücadeledeki gücünü göstermesi bakımından önemlidir. Mehmet Karakaş'ın ifadesiyle, Biz Bize Yeteriz Türkiyem kampanyası, küresel düzeyde gerçekleşen ve toplumları adeta bir korku tünelinin içerisine kapatan COVID-19 salgını karşısında, toplumların oluşturacağı dayanışma ruhu ve iradesi, salginla baş etme mücadelesinin en büyük gücüdür (Karakaş, 2020, s. 553). Türkiye salgınla mücadelede bu kampanyayla adeta bir milli seferberlik ilan etmiş ve toplumun geniş kesimleri bu kampanyaya katkı sunarak mücadeleye olan desteklerini ifade etmişlerdir. TÜBA'nın raporunda da görüldüğü üzere, Türkiye kendi tıbbî malzeme gereksinimleri yanı sıra talepler üzerine özellikle sağlık çalışanlarının temel izolasyon ve korunma ekipmanları konusunda kendi üretim ve stoklarından uluslararası dayanışma stratejisi 
çerçevesinde (İtalya, İspanya, İngiltere, İran, Bosna Hersek, Sırbistan, ABD, Çin, Pakistan, Somali, Sudan, Libya, Suriye ve Türki Cumhuriyetler vb.) yardım desteği sağlamıştır (TÜBA Raporu, 2020, s. 32). Türkiye'nin söz konusu ülkelere yardımda bulunması, Türkiye'nin küresel salgına karşı hazırlıklı olduğunu gösterdiği gibi, Türkiye'de milliyetçiliğinin toplumsal alanda dayanışma ve bütünleşmeyi içerdiğini ve toplumlararası alanda da işbirliği üzerinden örgütlendiğini göstermektedir.

Biz Bize Yeteriz Türkiyem kampanyası, her ne kadar ekonomik bir içeriğe sahip olsa da, esasında ekonominin yanı sıra Türkiye'de milliyetçiliğin toplumsal dayanışma, yardımlaşma ve bütünleşme süreçlerinde oynadığ rolü göstermesi bakımından önemlidir. Kampanya, salgın sürecinde Türkiye'nin kendi imkân ve potansiyelleri doğrultusunda nasıl örgütlendiğinin somut yansımalarını içermektedir. Küresel salgın karşısında her ulusdevletin kendi göbeğini kendisinin kestiği, bu anlamda çözümü başka yerde aramak yerine kendinde gördügü bir deneyimi göstermektedir. Kampanyanın isminde yer alan biz bize söylemi, Türkiye'de milliyetçiliğin sınırlar üzerinden bir kimlik inşa ettiğini göstermektedir. Biz bize söylemini daha iyi anlayabilmek için Zygmunt Bauman'ın biz ve onlar arasındaki ayrımı önemli katkılar sunmaktadır: Biz ve onlar yalnızca iki ayrı insan grubunu değil, tümüyle farklı iki tutum arasındaki, duygusal bağlanma ve antipati, güven ve kuşku, güvenlik ve korku, işbirliği ve çekişme arasındaki ayrımı temsil eder. Biz ait olduğumuz grup anlamına gelir. Bu grup içinde olanları gayet iyi anlarım ve anladığım için nasıl sürdüreceğimi bilirim, kendimi güvenli ve evimde hissederim. Bu grup adeta benim doğal ortamım, içinde olmaktan hoşlandığım ve huzur içinde döndügüum yerdir. Onlar ise tersine ne ait olmayı isteyebileceğim ne de istediğim bir grubu anlatır. Dolayısıyla o grupta neler olup bittiğine ilişkin gözümde canlanan şeyler, belli belirsiz ve kopuk kopuktur; o grubun işleyişine ilişkin pek bilgim yoktur ve yüzden o grubun yaptığı her ne ise benim için genelde kestirilemez ve aynı şekilde korkutucu şeylerdir (Bauman, 2013, s. 51). Bu bağlamda, Türkiye sinırları içerisinde kalan herkesin biz bize kategorisinde yer aldığı, buna karşın sınırların dışında kalanların ise onlardan olduğu vurgulanmaktadır. Bu vurgu, sınırların Türk ulusal kimliğinin toplumsal taşıyıcısı olduğunu, söz konusu kimliğin başlangıç ve bitiş noktalarını sembolize ettiğini ve salgınla topyekûn mücadelenin sınırların içerisinde kalarak yapıldığını içermektedir. 


\section{Sonuç}

COVID-19 salgını ve sınırlar ilişkisinin ele alındığı bu çalışmada, küresel salgın döneminde sınırların değişen anlamlarına odaklanılmıştır. Bu kapsamda, salgın koşullarında sınırlarla ilgili olarak elde edilen sonuçları şu şekilde toparlamak mümkündür:

1. Sınırlar, COVID-19 salgının yayılmasını önlemek amacıyla kapatılmıştır. Sınırların kapatılması işlevi, salgının başka ülke insanlarına bulaşmasını ya da başka ülkelerden gelen insan hareketliliğinin beraberinde taşıyacağı salgına dur diyebilmek için işlevsel hale gelmiştir. Bu anlamda sınırların koruma ve korunmayı sağlama gibi anlamları içerdiği görülmüştür.

2. Küreselleşme sınırların esnek, geçirgen, akışkan olduğunu, sınırların ortadan kalktığı bir dünyayı ve sınırsızlığın hakim olduğu bir anlayışı ifade ederken, sınırların meşruiyeti sorgulanır hale getirmiştir. Ancak küresel salgınla birlikte salgınla mücadelede sınırların artan önemi, değeri ve etkisi, bu kez küreselleşmenin sorgulanmasına sebebiyet vermiştir.

3. Hastalık küresel olsa da, tedavisi ulusaldır. Küresel salgınla mücadelede sınırlar, bu salgınla baş etmede önemli bir araç olmuştur. Salgınla mücadelenin ulusal olması, sınırların işlevlerini ön plana çıkardığı gibi, değerinin anlaşılmasına ve öneminin giderek artmasına da sebep olmuştur.

4. Sonuçları açısından salgın, sınırları aşan ve sınır tanımayan bir boyutta ortaya çıkarak sınırları işlevsiz hale getirirken, çözümler açısından salgın, sınırların etkin kullanımını, dolayısıyla da işlevsel rolünü ortaya çıkarmıştır. Küresel hastalığa yönelik bir ulusal tedavi aracı olan sınırlar, salgınla mücadelede sinırlı düzeyde de olsa etkili olmuştur. Her ne kadar sorun küresel olsa da, çözümün ulusal olması, sınırların etkisini daha fazla artırmıştır.

5. Küresel salgınla mücadelede, ulus-devletler sinırlar aracilı̆̆ıla mekanı ikili kategorik kimlikler üzerinden şekillendirmiştir. Ulus-devlet sınırlanı içerisinde yer alan mekandakiler, hijyenik, temiz, steril, sağlıklı olanı temsil ederken, ulusal sınırların dışında kalanlar ise, kirli, virüslü ve hastalıklı olarak kodlanmıştır. Sınırların içerisinin sağlıklı, dışarısının 
hastalıklı olarak görülmesi, sınırın dışında yer alanları içeride yer alanlar karşısında bir risk ve tehdit unsuruna dönüştürmüştür.

6. Küresel salgın karşısında sınırlar, ulusal izolasyonu sağlamanın temel aracı olmuştur. Her bir ulus-devlet, sınırlar aracılığıyla kendisini uluslararası ve küresel dünyadan izole ederek salgınla mücadele etmiştir. Ulusal izolasyonla birlikte her bir yurttaş, kendi ülkesinin sınırları içerisinde kalarak kendini farklı ülkelerden yalıtarak uzaklaştırmıştır. Ulusal düzeyde evdekal uygulaması, uluslararası ve küresel düzeyde yurttakal uygulamasına dönüşmüştür. Ulusal düzeyde hayat eve sığar uygulaması, uluslararası ve küresel düzeyde hayat yurda sığar uygulamasına dönüşmüştür. Ulusal izolasyonun sağlanmasına koşut bir biçimde, yurtta izolasyon cihanda izolasyon söylemi anlamlı bir karşılık bulmuştur.

7. Sınırlar, küresel salgınla mücadelenin etkin araçlarından biri olarak küreselleşmiş insan hareketliliğini düzenleme, denetleme, engelleme gibi işlevlere sahiptir. Küresel insan hareketlerinin sınır tanımayan özelliği karşısında sınırlar, salgının yayılmasını kontrol altına almak amacıyla söz konusu hareketliliği de kontrol altına almaktadır. Dahası, küresel insan hareketliliği içerisinde yer alan göçler de, salgın koşullarında denetlenmesi, düzenlenmesi ya da engellenmesi gereken oluşumlar olarak ön plana çıkmaktadır.

8. Küresel salgınla birlikte göçmenler, kirli, virüslü, hastalıklı kişiler olarak görülmeye başladığından, yaşadıkları toplumda ötekileştirmeye, dışlanmaya, kriminalize edilmeye maruz kalmaktadırlar. Artan seyahat yasakları, karantina uygulaması ve fiziksel mesafe kuralları, göçmenlerin hem göç etmelerini hem de göç ettikleri ülkelerden geriye dönüş göçlerini engellemekte, bu da ekonomik nedenli göçlerde göçmenlerin zor durumda kalmasina sebebiyet vermektedir.

9. Salgın öncesinde ulus-devletlerin uluslararası göçmenleri kontrol etmesi, denetlemesi ya da düzenlemesi eleştirilirken ve ulus-devletlerin küresel göç akımları karşısında meşruiyeti sorgulanırken, salgınla birlikte ulus-devletlerin salgını önleme, salgınla mücadele ya da salgına karşı koyma gerekçesiyle yapıp ettikleri meşru görülmeye başlanmış, bu da ulus-devletlerin küreselleşme karşısındaki meşruiyetini genişletmiştir.

10. Ulusal sınırların içerisinde yaşayanların virüssüz, dışarısında yaşayanların virüslü, içeridekilerin sağlıklı, dışarıdakilerin hastalıklı, içeridekile- 
rin temiz dişarıdakilerin kirli, içeridekilerin salgının bulaşmadığı dışarıdakilerin salgının bulaştığı şeklindeki ikili kategoriler, ulus-devletlerin sınırlar üzerinden milliyetçiliği yeniden ürettiğini, milliyetçi bir söylemin, milliyetçi bir kimliğin ve milliyetçi bir bakış açısının sınırlar aractlığıyla inşa edildiğini göstermektedir. Ulus-devletlerin sınırların dışarısında yer alanları kirli, virüslü ya da hastalıklı olarak kodlaması, kendisini sınırların dışarısında olanlardan üstün görme, sınırların içerisinde yer alanları biricikleştirme ve sınırların dışarısında yer alanları da kendinden aşağıda bir yerlerde tanımlama biçimidir ve bu da milliyetçiliğin hal-i pür melalini oluşturmaktadır.

11. Salgınla mücadelede ulus-devletler, virüse karşı aşı bulmak için birbirleriyle kıyasıya bir yarışın içerisinde girmiş, bu yarış milliyetçiliğin yükselişine yeni bir ivme katmıştır. Aşının bulunması çabası, milliyetçiliği koşullandıran, potansiyellerini ortaya çıaran ve başka milliyetçilikler karşısında kendi gücünü gösteren özellikler taşımaktadır. Küresel salgınla mücadelede milliyetçilik, toplumun motivasyon kaynağına dönüşmüştür. Toplumun tek vücut haline gelmesinde, milliyetçiliğin toplumsal, kültürel ve psikolojik anlamda bir motivasyon kaynağ etkili olmuştur.

12. Her ülkenin kendi imkân ve potansiyelleri doğrultusunda mücadele verdiği bu süreç, milliyetçiliğin yeniden dirilişi değil, daha ziyade dirilmiş milliyetçiliğin yeni, farklı ve değişik biçimlerde görünür olmasıdır. Salgınla birlikte milliyetçilik, aşı milliyetçiliği, Covid Milliyetçiliği, Corona milliyetçiliği gibi milliyetçilikler olarak isimlendirilmiştir.

13. Küresel salgınla mücadelede Türkiye, ulusal düzeyde başlatmış olduğu kampanyayla hem toplumsal desteği görünür kılmış hem de kendi imkan ve potansiyelleri bağlamında salgınla mücadele eder hale gelmiştir. Biz Bize Yeteriz Türkiyem adlı kampanyayla Türkiye, salgın koşullarında toplumun dezavantajlı kesimlerini desteklemiş ve ihtiyaç sahibi vatandaşlara yardımları dağıtmıştır.

14. Biz Bize Yeteriz Türkiyem kampanyası ekonomik bir hüviyete sahip olsa da, temelde milliyetçiliğin toplumsal dayanışmada, yardımlaşmada, bütünleşmede ne düzeyde etkili olduğunu göstermektedir. Biz Bize yeteriz söylemi ise, Türkiye'de salgın sürecinde sınırlar üzerinden milliyetçiliğin yeniden inşasını göstermektedir. Ulusal sınırlar içerisinde yer alanlar biz bize olanı işaret ederken, sınırların dışarısında kalanlar ise 
onlar olarak kodlanmıştır. Bu kodlama biçimi, milliyetçiliğin sınırların içerisinden dışarıya doğru yapıldığına işaret etmektedir.

15. Ulus-devletin geleceğinin sorgulandığı küreselleşme çağında, COVID19 salgını, ulus-devletin yeniden güçlenerek ortaya çıktığını göstermiştir. Salgının küreselleşme ve ulus-devlet ilişkisini bütünüyle olmasa bile, önemli ölçüde tersyüz ettiğini söylemek mümkündür. Diğer bir ifadeyle, küreselleşme karşısında meşruiyeti sorgulanan ulus-devletler, salgınla birlikte, yeniden güçlenerek tarih sahnesindeki yerini almıştır. Küresel gelişmeler karşısında etkisini önemli ölçüde kaybeden ulusdevletlerin halen temel aktör olduğu gerçeği, salgınla birlikte önemli ölçüde karşlık bulmuştur.

Neticede, COVID-19 salgınının küresel ölçekte yayılması, insan ve toplum yaşamını bütün boyutlarıyla etkilemiş, yaşamın bütün alanlarına nüfuz etmiş ve sonuçları itibariyle önemli değişimleri ortaya koymuştur. Küresel salgınla mücadelede, her bir ulus-devletin kendi kendine yeter anlayışla yer alması, hastalığın küresel olsa da, tedavisinin ulusal olduğunu göstermektedir. Ulus-devletler düzeyinde mücadelenin yapılması, kuşkusuz sınırların önemini, etkisini ve değerini daha da artırmıştır. Küreselleşmenin sınırsızlık, sınırötesilik, sınırsız dünya gibi fikirleri sebebiyle meşruiyeti sorgulanan sınırlar, salgınla birlikte sınırların önemi giderek artmaya başlamıştır. Sınırların kapatılmasıyla başlayan süreç, salgının önlenmesi kadar küreselleşme karşısında sınırların işlevselliğini de ön plana çıkarmıştır. Sınırların artan etkileri, küreselleşmenin sorgulanmasını beraberinde getirmiştir. Küreselleşme ve ulus-devlet tartışmalarındaki ana eğilimin bu salgınla birlikte değişime uğradığı, ulus-devletlerin halen temel bir aktör olduğu, salgınla birlikte küreselleşmenin sorgulandığı, sınırların salgınla mücadelede etkin birer araç olduğu, ulusal izolasyonu sağladığı, milliyetçiliğin inşasını sağladığı ve mekânı ulusal ölçekte yeniden örgütlediği, sınırların içerdiği anlamların nasıl değiştiğini göstermesi bakımından önemlidir. 


\title{
EXTENDED ABSTRACT
}

\section{COVID-19 and Borders: The Changing Meaning of Borders in a Global Pandemic}

\author{
Kerem Özbey \\ Artvin Coruh University
}

Borders have been closed to prevent the spread of the COVID-19 pandemic. The function of closing the borders has become functional in order to stop the epidemic from spreading to the people of other countries or to stop the epidemic that will be accompanied by human movement from other countries. While globalization expresses an understanding that borders are flexible, permeable and fluid, a world in which borders disappear, and an understanding dominated by limitlessness, the legitimacy of borders has become questioned. However, with the global epidemic, the increasing importance, value and effect of borders in combating the epidemic has led to the question of globalization this time. Although the disease is global, its treatment is national. In combating the global epidemic, borders have been an important tool in dealing with this epidemic. The fact that the fight against the epidemic is national not only brings the functions of the borders to the fore, but also has caused its value to be understood and its importance gradually increased. In terms of its consequences, the epidemic has emerged in a dimension that transcends borders and knows no boundaries, while making the borders dysfunctional, in terms of solutions, the epidemic has revealed the effective use of borders and therefore its functional role. Borders, a national treatment tool for global disease, have had a limited impact in combating the epidemic.

In the fight against the global epidemic, nation-states have shaped the space through dual categorical identities through borders. Those in the space within the borders of the nation-state represent the hygienic, clean, sterile and healthy, while those outside the national borders are coded as dirty, infected and diseased. The fact that the inside of the borders is seen as healthy and the outside as diseased has turned the areas outside the border into a risk and threat factor against those located inside. In the face of the global epidemic, borders have been the main means of ensuring national 
isolation. Each nation-state has struggled with the epidemic by isolating itself from the international and global world through borders. With the national isolation, each citizen stayed within the borders of his own country and distanced himself from different countries. The home application at the national level has turned into the home application at the international and global level. Life fits home at the national level has turned into a life fits home practice at the international and global level. In parallel with the provision of national isolation, the discourse of isolation in the homeland has found a meaningful response.

Borders have functions such as regulating, controlling, and blocking globalized human mobility as one of the effective tools to combat the global epidemic. In the face of the unlimited nature of global human movements, borders also control this mobility in order to control the spread of the epidemic. Moreover, migrations, which are included in the global human mobility, come to the fore as the formations that should be controlled, regulated or prevented in epidemic conditions. With the global epidemic, since immigrants are seen as dirty, infected and sick people, they are exposed to marginalization, exclusion and criminalization in their society. While the nation-states controlling, controlling or regulating international immigrants before the epidemic was criticized and the legitimacy of the nation-states against global migration flows was questioned, with the epidemic, the actions of the nation-states on the grounds of preventing the epidemic, fighting the epidemic or resisting the epidemic began to be seen as legitimate. it has expanded the legitimacy of nation-states against globalization.

The dual categories of those living within the national borders without viruses, those living outside with the virus, the healthy inside, the outside is healthy, the outside is clean, the outside is clean, the outside is contaminated by the epidemic, and the outside is infected by the epidemic, nation-states reproduce nationalism across borders, a nationalist discourse, a nationalist identity and a nationalist shows that the perspective is built through borders. The way nation states codify the areas outside the borders as dirty, infected or sickly, consider themselves superior to those outside the borders, uniqueize the areas within the borders, and define those located outside the borders somewhere below themselves, and this constitutes the state of nationalism. In the fight against the epidemic, nation-states have entered a fierce race with each other to find a vaccine against the virus, and this race has 
added a new momentum to the rise of nationalism. The search for the vaccine has features that condition nationalism, reveal its potential and show its strength against other nationalisms. In the fight against the global epidemic, nationalism has become the motivation source of the society. This process, in which each country struggles in line with its own possibilities and potentials, is not the resurgence of nationalism, but rather the appearance of resurrected nationalism in new, different and different forms.

Turkey in the fight against global secretions, that initiated the campaign at the national level as well as social support has made the fight against the epidemic would have become apparent in the context of their opportunities and potentials. We named Biz Bize Yeteriz Türkiyem campaign has supported the disadvantaged segments of society in epidemic conditions and has been distributing aid to needy citizens. Even though we have an economic identity Biz Bize Yeteriz Türkiyem campaign, social solidarity basically nationalism, in solidarity, what level shows that effective integration. We're the rhetoric enough for us, the epidemic shows the reconstruction process in Turkey over the limits of nationalism. Those who are within national borders are coded as them, while those outside the borders are coded as them. In the era of globalization where the future of the nation-state is being questioned, the COVID-19 epidemic has shown that the nation-state has emerged from strength again. It is possible to say that the epidemic has significantly reversed the relationship between globalization and the nation-state, if not completely.

\section{Kaynakça / References}

Bauman, Z. (2006). Küreselleşme: Toplumsal sonuçları. Çev. A. Yılmaz, İstanbul: Ayrınt Yayinları.

Bauman, Z. (2013). Sosyolojik düşünmek. Çev. A. Yılmaz, İstanbul: Ayrınt Yayınları.

Bieber, F. (2020). Global nationalism in times of the covid-19 pandemic. Nationalities Paper, 1-13.

Bozkurt, V. (2020). Pandemi döneminde çalı̧̧ma: Ekonomik kaygilar, dijitalleşme ve verimlilik. D. Demirbaş, V. Bozkurt ve S. Yorğun (Edt.), COVID-19 Pandemisinin Ekonomik, Toplumsal ve Siyasal Etkileri. İstanbul: İstanbul Üniversitesi Yayınları.

Buçukcu, Ö. (2020). Salgın milliyetçilikleri yükseltiyor mu?. L. Sunar (Edt.), COVID-19 Salginmin Sosyolojik Analizi, Toplumsal Yapı Araştırmaları Programı. 
Castles S. ve Miller M. J. (2008). Göçler çă̆ı: Modern dünyada uluslararası göç hareketleri. B.

U. Bal ve İ. Akbulut (Çev.), İstanbul: İstanbul Bilgi Üniversitesi Yayınları.

Daoudi, S. (2020). Vaccine nationalism in the context of covid-19: An obstacle to the containment of the pandemic. Policy Center for the New South.

Durgun, S. (2011). Memalik-i şahane'den vatan'a. İstanbul: İletişim Yayınları.

Giddens, A. (1994). Modernliğ̈in sonuçları. E. Kuşdil (Çev.), İstanbul: Ayrıntı Yayınları.

Hardt, M. ve Negri, A. (2012). Imparatorluk. A. Yılmaz (Çev.), İstanbul: Ayrıntı Yayınları.

Hirst, P. ve Thompson, G. (2003). Küreselleşme sorgulantyor. Ç. Erdem ve E. Yücel (Çev.), Ankara: Dost Kitabevi Yayınları.

Juergensmeyer, M. (2020). Covid nationalism. 22 Kasım 2020 tarihinde https://www.eir.info/2020/09/06/covid-nationalism/ adresinde erişildi.

Karabağ, S. (2014). Mekânın siyasallaşması. Ankara: Pegem Akademi Yayınları.

Karakaş, M. (2020). Covid-19 salgınının çok boyutlu sosyolojisi ve yeni normal meselesi. İstanbul Üniversitesi Sosyoloji Dergisi, 40(1), 541-573.

Karakılıç, İ. Z. ve Zırh, B. C. (2020). Göçmenlerin aynasından kovid-19 salgınında dünya. TESEV Değerlendirme Notları.

Masoom, M. R. (2016). Social isolation: A conceptual analysis. Research J. Humanities and Social Sciences, 7(4), 241-249.

Özkırıml, U. (2020). Coronationalism?, 22 Kasım 2020 tarihinde, https://www.opendemocracy.net/en/can-europe-make-it/coronationalism/ adresinden erişildi.

Robert, S., Woods, T., E. Greenfeld, L., Hughes, C. ve Miller-Idriss, C. (2020). Covid-19, nationalism, and the politics of crisis: a scholarly exchange. Nation and Nationalism, 1-19.

Robertson, R. (1999). Küreselleşme, toplum kuramı ve küresel kültür. Ü.Hüsrev Yolsal (Çev.), Ankara: Bilim ve Sanat Yayınları.

Samuel, K., Alkire, S., Hammock, J., Mills, C. ve Zavaleta, D. (2014). Social isolation and its relationship to multidimensional poverty. OPHI Working Paper No. 80, UK: University of Oxford.

Sirkeci, İ. ve Yüceşahin, M. M. (2020). Göç ve koronavirüs: Nüfus hareketliliği verileri üzerinden kovid-19 salgının analizi, Göç Dergisi, 7(1), 9-34.

Şahin, K. (2009). Küreselleşme tartışmalan işığında ulus-devlet. İstanbul: Yeniyüzyıl Yayınlari,.

Türk Dil Kurumu. (2020). Türk Dil Kurumu sözlükleri. 17 Aralı 2020 tarihinde https://sozluk.gov.tr/ adresinden erişildi. 
Türkiye Bilimler Akademisi. (2020). Covid-19 pandemi değerlendirme raporu. M. Şeker, A. Özer, Z. Tosun, C. Korkut ve M. Doğrul (Edt.), No:34, Ankara: Türkiye Bilimler Akademisi Yayınları.

Vogel, P. (2020). Nationalism: The even greater risk of the COVID-19 crisis, 22 Kasım 2020 tarihinde https://www.imd.org/research-knowledge/articles/Nationalismthe-even-greater-risk-of-the-COVID-19-crisis/ adresinden erişildi.

\section{Kaynakça Bilgisi / Citation Information}

Özbey, K. (2021). COVID-19 ve sinırlar: Küresel salgın döneminde sınırların değişen anlamı. OPUS-Uluslararası Toplum Araştırmaları Dergisi, 17(Pandemi Özel Sayıs1), 3699-3726. DOI: 10.26466/opus. 843330 